\title{
Applications of Whey as A Valuable Ingredient in Food Industry
}

\author{
Chandrajith VGG* and Karunasena GADV \\ Department of food science and technology, University of Sri Jayewardenepura, Nugegoda, Sri Lanka
}

Submission: July 06, 2018; Published: July 19, 2018

*Corresponding author: Chandrajith VGG, Department of food science and technology, University of Sri Jayewardanepura, No.3/3c, Kahapola, Madapatha, Sri Lanka, Tel: 0715236149; Email: gayanchandrajith1993@gmail.com

\begin{abstract}
Many scientific researches have been carried out on utilization of whey which is considered as a waste in dairy industry. It is hazardous to dispose whey directly in to the environment because several toxic substances are formed during decomposition of whey and it can cause several harmful consequences on the environment. Whey protein fraction consists of many useful nutrients that can be benefitial to human nutrition. This study presents the possible applications on whey in food industry and other fields and the possibility to recycle the whey incorporating them in to secondary dairy products.
\end{abstract}

Keywords: Applications; Dairy industry; Whey; Cheese; Salty whey; Sweet whey; Acid whey; Protein; Glycol; Milk solids; Phenylketonuriacs; Irradiation; Coagulation; Crystallization; Heptanal; Hexanal; Pentanal; 1-Hexen-3-one, 2-Pentylfuran; Octanal

\section{Nutrition Value of Whey}

When the nutrients in whey is concerned cheese, whey contains about $50 \%$ of milk solids, including almost $100 \%$ of the lactose and $20 \%$ of the total protein [1]. The recovery of such high-nutritional-value components from whey in a profitable way remains a topical challenge. Although whey was first considered to be a waste product and eliminated by the cheapest method possible, it is now being used to produce of a wide range of food products and food ingredients, such as whey-proteinbased ingredients [2]. Whey proteins are of several types: Sweet whey, Acid whey, Salty whey. Sweet whey differs from acid whey in terms of $\mathrm{pH}$ as well as concentrations of proteins, lactose, ash and minerals [3]. Total solid content, protein content lactose content, mineral content and several components determined in previous research [4] is shown in Table 1.

It has been determined that Bovine whey and individual whey protein exhibit antioxidant activity. This bioactivity is observed with different commercial whey products (Whey Protein Isolate, Whey Protein Concentrate), is relatively resistant to processing method, and is increased by enzymatic hydrolysis [5]. The absence of phenylalanine in glycol (caseino)macropeptide in whey protein makes it attractive for use in food formulations for phenylketonuriacs [6].

\section{Applications of Whey in Food Industry}

Whey can also be incorporated in to different food products to increase the nutrient level of the food products and several positive impacts could be brought about in food products by incorporating whey. Several previous researches have been carried out by altering different characteristics of whey. Possibility of incorporating whey in to cheese has been studied. The effect of the diameter of whey protein aggregate on the gel firmness has been studied. Regardless of whey origin, adding larger-diameter whey protein aggregates to cheese milk had no negative impact on rennet-induced coagulation, whereas smaller aggregates decreased curd firmness. Adding whey protein aggregates to milk increased cheese yield and moisture, and the dispersion method had no influence on these parameters, suggesting that a valve homogenizer is not required, which simplifies the process for artisanal cheese production [7] and it also has been found that the acid gels from milk with added whey protein had higher gel stiffness and yield stresses than those without added whey protein [8]. Studies also showed that the addition of $1 \%$ whey protein concentrate to milk before heating almost doubled the stiffness of acid gels prepared from the milk the protein content was increased, and the fat content was decreased by adding whey protein aggregates to milk, suggesting good retention of added protein, or reduced retention of fat in cheese [9].

The effect in enriching food systems with Microparticulate whey protein and Nanoparticulated whey protein has been studied and the results showed that the formation of disulphidelinked structures in milk model systems was closely related to 
the increased particle size and rheological behavior of the gels. Microparticulated whey protein enriched systems produced, upon acidification, weak protein networks and required the addition of whey protein isolate (WPI) to increase gel strength.

Table 1: Components in different types of whey [4].
However, systems containing Nanoparticulate whey protein exhibited pronounced increase in particle size and higher firmness of acidified gels through both covalent and non-covalent interactions [10].

\begin{tabular}{|c|c|c|c|c|}
\hline Component & Native whey & Sweet whey & Acid whey & Salty whey \\
\hline Total solid (\%) & $2.5 \pm 0.01^{\mathrm{a}}$ & $16.8 \pm 0.01^{\mathrm{b}}$ & $2.86 \pm 0.07^{c}$ & $8.9 \pm 0.01^{\mathrm{d}}$ \\
\hline Ash (\%) & $0.2 \pm 0.003^{\mathrm{a}}$ & $0.7 \pm 0.08^{b}$ & $0.21 \pm 0.01^{\mathrm{a}}$ & $1.7 \pm 0.11^{\mathrm{c}}$ \\
\hline Total protein (\%) & $2.2 \pm 0.01^{\mathrm{a}}$ & $10.8 \pm 0.4^{\mathrm{b}}$ & $1.73 \pm 0.01^{c}$ & $1.0 \pm 0.1^{\mathrm{c}}$ \\
\hline Non-protein nitrogen (\%) & $0.005 \pm 0.001^{\mathrm{a}}$ & $0.01 \pm 0.0^{\mathrm{a}}$ & $0.006 \pm 0.001^{\mathrm{a}}$ & $0.01 \pm 0.0^{\mathrm{a}}$ \\
\hline $\mathrm{pH}$ & $6.5 \pm 0.03^{\mathrm{a}}$ & $6.4 \pm 0.02^{\mathrm{b}}$ & $4.2 \pm 0.02^{c}$ & $5.5 \pm 0.01^{\mathrm{d}}$ \\
\hline Lactose (\%) & $0.1 \pm 0.02^{\mathrm{a}}$ & $2.9 \pm 0.03^{b}$ & $0.7 \pm 0.02^{c}$ & $2.4 \pm 0.3^{c}$ \\
\hline Lactic acid (\%) & $0.001 \pm 0.0001^{\mathrm{a}}$ & $0.1 \pm 0.03^{b}$ & $0.2 \pm 0.02^{c}$ & $0.07 \pm 0.001^{b}$ \\
\hline $\mathrm{Ca}\left(\mathrm{mg} 100 \mathrm{~g}^{-1}\right)$ & $40 \pm 1^{\mathrm{a}}$ & $20 \pm 3^{b}$ & $140 \pm 10^{c}$ & $80 \pm 1^{\mathrm{c}}$ \\
\hline $\mathrm{K}\left(\mathrm{mg} 100 \mathrm{~g}^{-1}\right)$ & $30 \pm 1^{\mathrm{a}}$ & $100 \pm 20^{\mathrm{b}}$ & $10 \pm 0.0^{\mathrm{a}}$ & $50 \pm 6^{a}$ \\
\hline $\operatorname{Mg}\left(\mathrm{mg} 100 \mathrm{~g}^{-1}\right)$ & $20 \pm 1^{\mathrm{a}}$ & $10 \pm 1^{\mathrm{b}}$ & $10 \pm 1^{\mathrm{b}}$ & $10 \pm 6^{\mathrm{b}}$ \\
\hline $\mathrm{Na}\left(\mathrm{mg} 100 \mathrm{~g}^{-1}\right)$ & $10 \pm 4^{\mathrm{a}}$ & $400 \pm 20^{\mathrm{a}}$ & $30 \pm 10^{\mathrm{b}}$ & $1100 \pm 50^{\mathrm{b}}$ \\
\hline $\begin{array}{l}\text { Inorganic phosphate (mg } \\
\left.100 \mathrm{~g}^{-1}\right)\end{array}$ & $10 \pm 6^{\mathrm{a}}$ & $10 \pm 3^{\mathrm{a}}$ & $3 \pm 1^{\mathrm{a}}$ & $10 \pm 3^{\mathrm{a}}$ \\
\hline Total phosphate (mg $100 \mathrm{~g} \mathrm{~g}^{-1}$ ) & $20 \pm 2^{\mathrm{a}}$ & $30 \pm 6^{a}$ & $10 \pm 3^{\mathrm{a}}$ & $20 \pm 1^{a}$ \\
\hline
\end{tabular}

Values are means \pm standard deviation (SD) means of at least 4 independent measurements $(n \geq 4)$; different lowercase superscripts in the same row depict the significant difference between means for each whey concentrate.

Nanoparticulate whey protein are used as ingredients for fat replacement in several food products, such as ice cream, fermented milk, cheese, sauces and dressings. Such particles can be manufactured in diameters ranging from 1 to $10 \mathrm{~mm}$. Nanoparticulate whey protein can also act as emulsifiers and fat substitutes but exhibit smaller particle sizes [11]. The use of whey proteins as texture enhancers in yoghurt has become a common practice due to their nutritional and functional properties [12,13]. Developing of aerogels is another possible application of whey. Blending whey protein with alginate allowed for the production of bio-based aerogels with better mechanical properties than those produced with whey alone, though thermal properties was slightly decreased by blending [14].

Whey proteins can also be used for encapsulation. Whey protein concentrate could delay the photodecomposition of folic acid and the protective effect increased gradually during irradiation and the increase in the absorbance at $365 \mathrm{~nm}$ and antioxidant activity of Whey protein concentrate contributed to the protein improved protection against the decomposition of folic acid. Whey protein concentrate could thus be a good carrier material for the protection of folic acid [15]. According to the in vitro digestibility tests, the whey proteins isolate had the ability to protect the anthocyanins in the stomach, while the microencapsulated powder displayed a stimulatory effect on the growth and viability of L. casei $431 \circledR[16]$.

A study showed that formation of nanocomplexes between pectin and whey protein concentrate as wall materials was capable of encapsulating appreciable amounts of d-limonene.
The optimum whey protein concentrates pectin nanocomplex containing d-limonene can be used in products such as cakes, muffins, biscuits, juices etc. since this vital flavoring can be protected in products during processing and storage and its release can be controlled [17].

Whey protein fortified foods and beverages are becoming increasingly popular, particularly among consumers that are active in sports for physique building purposes. Heat treatment of whey protein isolate solutions (5 to $10 \%$ ) at low pH resulted in formation of protein fibrils, which led to a pronounced increase in the viscosity of the protein solutions (from 1.6 to $2300 \mathrm{mPa}$ ) due to the increased effective volume and the rate of energy dissipation. High-pressure processing (microfluidization) could be used to decrease the mean length of the fibrils (from around 310 to $97 \mathrm{~nm}$ ) and therefore alter their thickening characteristics. The turbidity of all the whey protein solutions increased to greater than $1 \mathrm{~cm}^{-1}$ near the isoelectric point, which was attributed to extensive protein aggregation due to weakening of the electrostatic repulsion between the molecules [18].

\section{Different treatments on whey}

Ultrasound treatment has been applied in previous research. The effect of ultrasound power and exposure time of pretreatment on lactose recovery has also been investigated. Ultrafiltration has been subsequently used for the separation of proteins and lactose from whey followed by anti-solvent son crystallization of lactose using ethanol. Combined pretreatment using ultrasound and heating resulted in maximum recovery [19] Ultrasound treatment on post thermal aggregation has improving effect 
on physiochemical and emulsifying properties of whey protein soluble aggregates for potential industrial applications. There was a significant reduction in turbidity of whey protein solutions by ultrasound. The apparent viscosity of whey protein soluble aggregate model systems has been decreased significantly influenced by ultrasound pre- and post- thermal aggregation. Emulsion activity index and emulsion stability index of soluble aggregates were increased significantly by ultrasound applied post-thermal aggregation [20].

Application of membrane technologies such as Microfiltration has been studied previous for whey protein. The Micro filtration and Hydrogen Peroxide and Lacto Peroxidase bleached $80 \%$ Whey protein concentrate displayed a 39.5, 40.9, and $92.8 \%$ norbixin decrease, respectively. The Hydrogen Peroxide and Lacto Peroxidase $80 \%$ Whey protein concentrate had higher cardboard flavors and distinct cabbage flavor compared with the unbleached and Micro filtration 80\% Whey protein concentrate. Volatile compound results were consistent with sensory results. The Hydrogen Peroxide and Lacto Peroxidase $80 \%$ Whey protein concentrate were higher in lipid oxidation compounds (especially heptanal, hexanal, pentanal, 1-hexen-3-one, 2-pentylfuran, and octanal) compared with unbleached and Micro filtration $80 \%$ Whey protein concentrate. Micro filtration is a viable alternative to chemical or enzymatic bleaching of fluid whey [21].

\section{Techniques that Can be used to Analyze Whey}

The FTIR analysis method uses infrared light to scan test samples and observe chemical properties. Each molecule or chemical structure will produce a unique spectral fingerprint, making FTIR analysis a great tool for chemical identification. FTIR spectroscopy is an established technique for quality control when evaluating industrially manufactured material and can often serve as the first step in the material analysis process. If problems with the product are identified by visual inspection, the origin is typically determined by FTIR microanalysis. This technique is useful for analyzing the chemical composition of smaller particles, typically $10-50$ microns, as well as larger areas on the surface.

Confocal Laser Scanning Microscopy (CLSM) is convenient and effective instrument for relatively quick 2-and 3D imaging of fracture surfaces. At least on the scale of the region as small as $128 \times 128 \mu \mathrm{m}$ the $2 \mathrm{D}$ images clearly representing all elements of the brittle cleavage fracture surfaces can be obtained by CLSM. The resolution and quality of such images is high enough to rival with those captured by SEM at the same magnification [22]. A primary use of circular dichroism is in analyzing the secondary structure or conformation of macromolecules, particularly proteins as secondary structure is sensitive to its environment, temperature or $\mathrm{pH}$, circular dichroism can be used to observe how secondary structure changes with environmental conditions or on interaction with other molecules. Structural, kinetic and thermodynamic information about macromolecules can be derived from circular dichroism spectroscopy.ia.

\section{References}

1. Bansal N, Bhandari B (2016) Functional milk proteins: production and utilization- whey-based ingredients. In: McSweeney, PLH, O'Mahony JA (Eds.), Advanced dairy chemistry. Springer, New York, USA, p. 67-98.

2. Fox PF, Guinee TP, Cogan TM, McSweeney PLH (2000) Whey and whey products. In: Fox PF, Guinee TP, Cogan TM, McSweeney PLH (Eds.), Fundamentals of cheese science Gaithersburg, MD, Aspen Publishers, USA, pp. 514-522.

3. Lievore P, Simoes DRS, Silva KM, Drunkler NL, Barana AC, et al. (2015) Chemical characterisation and application of acid whey in fermented milk. J Food Sci Technol 52(4): 2083-2092.

4. Manjula Nishanthi, Jayani Chandrapala, Todor Vasiljevic (2017) International Dairy Journal. 74: 49-56.

5. Alberto R Corrochano, Vitaly Buckin, Phil M Kelly, Linda Giblin (2018) Whey proteins as antioxidants and promoters of cellular antioxidant pathways. Journal of Dairy Science 101(6): 4747-47610.

6. Jodi Pilbrow, Alaa El-din A Bekhit, Alan Carne (2016) Fractionation of sheep cheese whey by a scalable method to sequentially isolate bioactive proteins. Food Chemistry 203: 165-174.

7. Helene J Giroux, Noemie Veillette, Michel Britten (2018) Use of denatured whey protein in the production of artisanal cheeses from cow, goat and sheep milk. Small Ruminant Research 161: 34-42

8. Skelte G Anema (2018) Effect of whey protein addition and pH on the acid gelation of heated skim milk, International Dairy Journal 79: 5-14.

9. Lucey JA, Munro PA, Singh H (1999) Effects of heat treatment and whey protein addition on the rheological properties and structure of acid skim milk gels. International Dairy Journal 9: 275-279.

10. Guanchen Liu, Tanja C Jæger, Marianne N Lund, Søren B Nielsen, Colin A Ray, et al. (2016) Effects of disulphide bonds between added whey protein aggregates and other milk components on the rheological properties of acidified milk model systems. International Dairy Journal 59: 1-9.

11. Renard D, Lavenant L, Sanchez C, Hemar Y, Horne D (2002) Heatinduced flocculation of microparticulate whey proteins (MWP); consequences for mixed gels made of MWP and b-lactoglobulin. Colloids and Surfaces B: Bio interfaces 24: 73-85.

12. de Wit JN (1998) Nutritional and functional characteristics of whey proteins in food products. Journal of Dairy Science 81(3): 597-608.

13. Hau J, Bovetto L (2001) Characterization of modified whey protein in milk ingredients by liquid chromatography coupled to electrospray ionization mass spectrometry. Journal of Chromatography 926(1): 105-112.

14. Hong-Bing Chen, Yu-Zhong Wang, David A Schiraldi (2013) Foam-like materials based on whey protein isolate. European Polymer Journal 49(10): 3387-3391.

15. Xiaojun Fu, Wusigale Hao Cheng Zheng Fang, Li Liang (2018) Mechanism for improved protection of whey protein isolate against the photodecomposition of folic acid. Food Hydrocolloids 79: 439-449.

16. Ana-Maria Oancea, Mahadi Hasan, Aida Mihaela Vasile, Vasilica Barbu, Elena Enachia, et al. (2018) Functional evaluation of microencapsulated anthocyanins from sour cherries skins extract in whey proteins isolate. LWT - Food Science and Technology 95: 129-134

17. Sanaz Ghasemi, Seid Mahdi Jafari, Elham Assadpour, Morteza Khomeiri (2018) Nanoencapsulation of d-limonene within nanocarriers produced by pectin-whey protein complexes. Food Hydrocolloids 77: 152-162.

18. Charmaine KW Koo, Cheryl Chung, Thaddao Ogren, William Mutilangi, David Julian McClements (2018) Extending protein functionality: 
Microfluidization of heat denatured whey protein fibrils. Journal of Food Engineering 223: 189-196.

19. Rajeshree A Khaire, Parag R Gogate (2018) Intensified Recovery of Lactose from Whey using Thermal. Ultrasonic and Thermosonication Pretreatments, Journal of Food Engineering 237: 240-248.

20. XueShena Tianqi Fanga FengGaoa Mingruo Guo (2017) Effects of ultrasound treatment on physicochemical and emulsifying properties of whey proteins pre- and post-thermal aggregation. Food Hydrocolloids 63: 668-676.

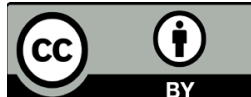

This work is licensed under Creative Commons Attribution 4.0 License DOI: 10.19080/JDVS.2018.06.555698
21. Qiu TY Smith J, Foegeding EA, Drake MA (2018) The effect of microfiltration on color, flavor, and functionality of $80 \%$ whey protein concentrate. Journal of Dairy Science 598(9): 5862-5873.

22. Merson E, Danilov V, Merson D, Vinogradov A (2017) Confocal laser scanning microscopy: The technique for quantitative fractographic analysis, Engineering, Fracture Mechanics. 183: 147-158.

\section{Your next submission with Juniper Publishers will reach you the below assets}

- Quality Editorial service

- Swift Peer Review

- Reprints availability

- E-prints Service

- Manuscript Podcast for convenient understanding

- Global attainment for your research

- Manuscript accessibility in different formats ( Pdf, E-pub, Full Text, Audio)

- Unceasing customer service

Track the below URL for one-step submission https://juniperpublishers.com/online-submission.php 